\title{
OPIOID-INDUCED CONSTIPATION IN PALLIATIVE CARE: STATE OF THE ART
}

\section{Constipação induzida por opióides em cuidado paliativo: o estado da arte

\author{
Presión de vientre induzida por opióides en cuidado paliativo: el estado \\ del arte
}

Geslaney Reis da Silva ${ }^{1}$, Erlania do Carmo Freitas ${ }^{2}$, Rudval Souza da Silva ${ }^{3}$, Maria Patrícia Milagres ${ }^{4}$, Rita Narriman Silva de Oliveira Boery ${ }^{5}$

How to cite this article:

Silva GR, Freitas EC, Silva RS, Milagres MP, Boery RNSO. Opioid-induced constipation in palliative care: state of the art. 2020 jan/dez; 12:1116-1124. DOI: http://dx.doi.org/0.9789/2175-5361.rpcfo.v12.8008.

\begin{abstract}
Objective: The study's purpose has been to address the state of the art in investigations such as clinical trials, systematic reviews with meta-analysis and case studies, which report how to minimize opioid-induced constipation in patients undergoing palliative care. Methods: This is an exploratory study through an integrative review of four databases addressing published articles from 2013 to 2017. Results: A total of 117 publications were presented, which 17 presented the inclusion criteria. The studies describe the prevalence of constipation rates induced by the use of opioids. Conclusion: Although these drugs alleviate pain, the adverse reactions may generate discomfort and loss of the patient's life quality. There are limited data on the treatment of constipation. It was observed that few authors mentioned diet as a helper on this situation, emphasizing the use of medications. Further studies should be encouraged aiming to find the balance between analgesia and reduction of adverse effects.
\end{abstract}

Descriptors: Morphine, constipation, palliative care, nursing and health, nutrition.

\section{RESUMO}

Objetivo: Objetivou-se realizar o estado da arte de publicações que relatem estratégias de como minimizar a constipação induzida pelo uso de opióides, de pacientes em cuidado paliativo. Método: Trata-se de um estudo exploratório através de uma revisão integrativa em quatro bases de dados de artigos publicados entre os anos de 2013 a 2017. Resultados: Evidenciaram-se 117 publicações, as quais 17 apresentaram os critérios de inclusão da pesquisa. Conclusão: Apesar das drogas aliviarem a dor, as reações adversas geram desconforto e perda da qualidade de vida. Existem dados limitados referentes ao tratamento da constipação intestinal em cuidado paliativo. Observou-

1 Nursing Graduate by the Universidade Federal da Bahia (UFBA), MSc in Nursing and Health by the Nursing and Health Postgraduate Program from the UESB, Professor at the Universidade Maurício de Nassau (UNINASSAU), Brazil.

2 Nutrition Graduate by the Faculdade de Tecnologia e Ciências (FTC), PhD Student (fellowship holder) in Nursing and Health by the Nursing and Health Postgraduate Program from the Universidade Estadual do Sudoeste da Bahia (UESB), Brazil.

3 Nursing Graduate by the Universidade Católica de Salvador (UCSAL), PhD in Nursing by the Nursing School from the UFBA, Adjunct Professor at the Universidade do Estado da Bahia (UNEB), Brazil.

4 Graduate in Dairy Science and Technology by the Universidade Federal de Viçosa (UFV), PhD in Food Science and Technology by the $U F V$, Adjunct Professor at the UESB.

5 Nursing Graduate by the UFBA, Postdoc in Bioethics by the Universidade Católica Portuguesa (UCP), Full Professor at the UESB. 
se que poucos autores mencionaram a dieta como auxiliador no quadro, enfatizando o uso de medicamentos. Mais estudos devem ser estimulados no intuito de encontrar o equilíbrio entre analgesia e redução de efeitos adversos causados pelos opióides.

Descritores: Morfina; Constipação; Cuidados paliativos.

\section{RESUMÉN}

Objetivo: Se objetivó realizar el estado del arte de publicaciones que relatan estrategias de cómo minimizar el constipación inducida por el uso de opioides, de pacientes en cuidado paliativo. Método: Se trata de un estudio exploratorio a través de una revisión integrativa en cuatro bases de datos de artículos publicados entre los años de 2013 a 2017. Resultados: Se evidenció 117 publicaciones, las cuales 17 presentaron los criterios de inclusión de la investigación. Conclusión: A pesar de las drogas aliviar el dolor, las reacciones adversas generan incomodidad y pérdida de la calidad de vida. Existen datos limitados referentes al tratamiento de estreñimiento intestinal en el cuidado paliativo. Se observó que pocos autores mencionaron la dieta como auxiliador en el cuadro, enfatizando el uso de medicamentos. Más estudios deben ser estimulados con el fin de encontrar el equilibrio entre analgesia y reducción de efectos adversos causados por los opioides.

Descriptores: Morfina; Presión de vientre; Cuidados paliativos.

\section{INTRODUCTION}

Pain is one of the most experienced anxieties in cancer patients. Despite so many beliefs and fears about opioid use, old World Health Organization (WHO) publications ${ }^{1}$ supported by recent international guidelines ${ }^{2,3}$ for the pharmacological treatment of cancer pain in its moderate to severe stages, suggest that the use of opioids is the best therapy, evidencing the use of morphine ${ }^{4}$. Nevertheless, side effects such as opioid-induced constipation deserve highlighting ${ }^{5,6}$.

Studies report the increased prevalence of neoplasms, Non-communicable Chronic Diseases (NCDs) and other diseases, generating morbidity with sequelae and disabilities, progressing to the association of palliative care ${ }^{5,7}$. Using palliative care treatment against the disease without expectation of cure is still a matter of conflict.

The $\mathrm{WHO}^{8}$ defines that Palliative Care is active total care with an approach that promotes the quality of life of patients and their families, who face life-threatening diseases and do not respond to curative treatment by preventing and relieving suffering ${ }^{5,6,9}$.

Opioids are the most effective drugs of choice in the treatment of moderate to severe pain, especially in advanced and malignant disease ${ }^{2,10}$. Opioid receptors are distributed in cells of the body, especially those of the neural and intestinal systems. By activating $\mu$-receptors in the intestine, opioids do reduce the release of acetylcholine and other neurotransmitters that control the enteric muscle contractions responsible for propulsive activity, leading to increased fluid absorption and decreasing intestinal secretion that dries out the fecal bolus, reducing the spasms of the colon and anal sphincter, leading to constipation and also gastroparesis. Patients complain of incomplete bowel movement, abdominal distension, gas accumulation, among others ${ }^{10}$.

Cancer patients may develop severe constipation that is usually aggravated by morphine therapy ${ }^{11}$. The effects of opioids are distressing, to the point that patients prefer to give up the use of these drugs ${ }^{12,13}$. Research has reported that opioid-induced constipation is estimated at $40 \%$ to $70 \%$ of people receiving opioids. In contrast, there are constipation events in palliative care that are not related to the use of opioids, it is suggested that inappetence, nausea, and vomiting that reduce food intake, evolve to constipation ${ }^{4,10,14}$.

Considering this perspective, the present study aims to perform an integrative literature review of the latest publications between the years 2013 to 2017 of clinical trials, systematic reviews with meta-analysis and case studies that address topics such as minimizing signs and symptoms caused by the use of opioids in patients under palliative treatment.

\section{METHODS}

This is an integrative literature review based on the state of the art. For the bibliographic survey, three controlled descriptors were selected and identified in the Health Sciences Descriptors (DeCS) database of the Centro Latino-Americano e do Caribe [Latin American and Caribbean Center] on Health Sciences Information: "Constipation"; "Palliative Care"; "Morphine" and the "and" and "or" Boolean operators following the steps proposed by Ércole et al. ${ }^{27}$. The research question was elaborated as follows: How to reduce the symptoms of opioid-induced constipation in patients undergoing palliative care using morphine?

There were included articles published in peer-reviewed journals using methodologies with randomized clinical trials with children and adults, case studies and systematic reviews with meta-analysis published from 2013 to 2017, in English, Spanish and Portuguese, addressing studies with palliative care patients who use morphine or other opioids as therapy for moderate to chronic pain and who have developed opioid-induced constipation.

Guidelines were excluded, articles that had conflicts of interest and did not have a clinical trial, articles that had restricted access in which the main authors did not respond to the requested electronic correspondences to date $(n=5)$, articles with animal research; bibliographic reviews without meta-analysis; articles dealing with chronic opioid pain but without palliative care; and research that did not match the outcome of the research and did not answer the guiding question proposed.

The search strategies used in the literature were articles available in the databases of the Virtual Health Library (VHL), Coordenação de Aperfeiçoamento de Pessoal de Nível Superior (CAPES) [Coordination for the Improvement of Higher Education Personnel], SAGE Journals, PubMed and 
to avoid confirmation bias, systematic reviews were used at The Cochrane Library - Cochrane Reviews database over the period from September to October 2017.

To categorize the selected studies, 45 articles were found in the CAPES database; in the VHL 09 articles, 04 in common with those found in CAPES; In SAGE Journals, 61 articles were found, with 09 in common with the CAPES database, 04 reviews in the Cochrane Library database, 03 in common to those found in the CAPES database, and 18 articles found in the PubMed database: 04 in common with the findings in the CAPES database, 01 common in the Cochrane database, 13 new articles, where 07 articles addressing the theme were used. In the end, 117 articles were found in the research databases.

A critical assessment of the located articles was performed and soon after the critical analysis of the 117 articles found, only 17 articles fit the inclusion criteria of the present research, of which 11 studies were clinical trials, 02 case studies and 04 systematic reviews with meta-analysis.

\section{RESULTS}

The articles with clinical trials that have proven opioid-induced constipation in palliative care and suggest some type of therapy for constipation control, and two case reports, are presented in Table 1.

Table - 1 - Articles showing opioid-induced constipation in palliative care patients.

\begin{tabular}{|c|c|c|c|c|}
\hline Authors & Sample & $\begin{array}{l}\text { Objective of } \\
\text { the study }\end{array}$ & Methods & Results \\
\hline $\begin{array}{l}\text { GRETTON } \\
\text { et al. }{ }^{5}\end{array}$ & $\begin{array}{l}228 \text { patients using } \\
\text { morphine for more } \\
\text { than } 30 \text { days. }\end{array}$ & $\begin{array}{l}\text { Investigate the } \\
\text { association } \\
\text { between plasma } \\
\text { morphine } \\
\text { concentrations and } \\
\text { clinical effects of } \\
\text { morphine in cancer } \\
\text { patients }\end{array}$ & $\begin{array}{l}\text { Prospective observational } \\
\text { clinical trial of cancer patients } \\
\text { who use oral morphine for } \\
\text { moderate to severe pain. }\end{array}$ & $\begin{array}{l}\text { No significant association was } \\
\text { observed between plasma morphine } \\
\text { and metabolite concentrations and } \\
\text { other side effects (nausea, vomiting, } \\
\text { constipation, diarrhea). The authors } \\
\text { suggest that side effects are associated } \\
\text { with dosing and that interindividual } \\
\text { variation in morphine bioavailability } \\
\text { may influence these findings. }\end{array}$ \\
\hline $\begin{array}{l}\text { YEOMANSO, } \\
\text { CHOHAN e } \\
\text { MAYER }{ }^{15}\end{array}$ & $\begin{array}{l}\text { Male child } 03 \text { years } \\
\text { old with widely } \\
\text { metastatic alveolar } \\
\text { rhabdomyosarcoma. }\end{array}$ & $\begin{array}{l}\text { Observe the } \\
\text { effects of the drug } \\
\text { Methylnaltrexone in } \\
\text { a child undergoing } \\
\text { oncologic } \\
\text { treatment with } \\
\text { opioid-induced } \\
\text { constipation. }\end{array}$ & $\begin{array}{l}\text { Case study of a child using } \\
\text { opioids ( } 120 \text { mg intravenous } \\
\text { diamorphine/24h continuously } \\
\text { infused) evolving with opioid- } \\
\text { induced constipation used } \\
\text { sodium laxative docusate } \\
\text { and sodium picosulfate for a } \\
\text { short time because it had an } \\
\text { unpleasant taste where it was } \\
\text { prescribed Methylnaltrexone. }\end{array}$ & $\begin{array}{l}\text { The child experienced a very large } \\
\text { volume of stool within } 10 \text { minutes } \\
\text { of Methylnaltrexone ( } 150 \mathrm{mcg} / \mathrm{kg} \\
\text { intravenously), where there was no } \\
\text { reduction in opioid half-life while } \\
\text { maintaining pain control. It shows the } \\
\text { effectiveness of using a constipation } \\
\text { controller against opioid treatment. }\end{array}$ \\
\hline $\begin{array}{l}\text { DHINGRA } \\
\text { et al. }{ }^{16}\end{array}$ & $\begin{array}{c}169 \text { patients, } \\
\text { where } 68 \text { had } \\
\text { advanced cancer } \\
\text { and opioid-induced } \\
\text { constipation. } \\
\text { Considering the } 68 \\
\text { patients, } 17 \text { used } \\
\text { oral laxatives or } \\
\text { enemas for more } \\
\text { than } 3 \text { days a week } \\
\text { and of these only } 12 \\
\text { participated in } \\
\text { the interview. }\end{array}$ & $\begin{array}{l}\text { Use qualitative } \\
\text { research methods } \\
\text { to better } \\
\text { understand } \\
\text { psychological } \\
\text { distress and burden } \\
\text { associated with } \\
\text { opioid-induced } \\
\text { constipation and } \\
\text { its treatment in } \\
\text { advanced cancer } \\
\text { patients }\end{array}$ & $\begin{array}{l}\text { Qualitative study with thematic } \\
\text { content analysis, with semi- } \\
\text { structured interviews with } \\
\text { questions that guide the } \\
\text { perception of psychological } \\
\text { distress of opioid-induced } \\
\text { constipation symptoms. } \\
\text { Patients had been on opioids } \\
\text { daily for more than } 4 \text { weeks } \\
\text { (Hydromorphone IV; Fentanyl; } \\
\text { Oxycodone; Methadone) } \\
\text { and had self-reported } \\
\text { constipation, where they used } \\
\text { oral laxative or enema for more } \\
\text { than } 3 \text { days a week. }\end{array}$ & $\begin{array}{l}\text { It was observed that the patients } \\
\text { had psychological distress such as } \\
\text { depressive changes and anticipatory } \\
\text { anxiety related to constipation. } \\
\text { And they believed in the power of a } \\
\text { high-fiber diet to minimize the effects } \\
\text { of constipation. The authors suggest } \\
\text { the use of medications to minimize } \\
\text { opioid side effects. }\end{array}$ \\
\hline
\end{tabular}




\begin{tabular}{|c|c|c|c|c|}
\hline Authors & Sample & $\begin{array}{l}\text { Objective of } \\
\text { the study }\end{array}$ & Methods & Results \\
\hline $\begin{array}{l}\text { NEEFJES } \\
\text { et al. }{ }^{17}\end{array}$ & $\begin{array}{c}195 \text { Palliative care } \\
\text { patient using } \\
\text { morphine }(n=78), \\
\text { oxycodone }(n=78) \\
\text { and fentanyl }(n=39) \\
\text { who will receive } \\
\text { Methylnaltrexone } \\
\text { according to weight } \\
\text { for laxation. }\end{array}$ & $\begin{array}{l}\text { The overall } \\
\text { objective is to } \\
\text { determine the } \\
\text { effectiveness of } \\
\text { Methylnaltrexone } \\
\text { prescribing for } \\
\text { the treatment of } \\
\text { opioid-induced } \\
\text { constipation in } \\
\text { patients using } \\
\text { morphine, } \\
\text { oxycodone and } \\
\text { fentanyl, and to } \\
\text { explore the effects } \\
\text { of methylnaltrexone } \\
\text { immunomodulators } \\
\text { and antiangiogenics. }\end{array}$ & $\begin{array}{l}\text { A randomized, prospective, } \\
\text { parallel multicenter clinical trial } \\
\text { will assess the effectiveness } \\
\text { of methylnaltrexone among } \\
\text { palliative care patient groups } \\
\text { using different types of opioids, } \\
\text { clinic users, ambulatory clinic } \\
\text { and hospital wards in the } \\
\text { Netherlands. In patients who } \\
\text { did not evacuate within } 03 \text { days } \\
\text { of the week or no evacuation in } \\
\text { the last } 24 \text { or } 48 \text { hours and who } \\
\text { have a clinical indication for } \\
\text { methylnaltrexone use. }\end{array}$ & $\begin{array}{l}\text { For the laxative effect of the drug, } \\
\text { it was noted that patients treated } \\
\text { with morphine sulfate, oxycodone and } \\
\text { fentanyl complained of constipation } \\
\text { in } 70,75 \text { and } 40 \% \text {, respectively, } \\
\text { and after intervention improvements } \\
\text { were observed in } 60 \% \text { of morphine } \\
\text { patients; } 60 \% \text { of oxycodone patients } \\
\text { and } 25 \% \text { of patients in the fentanyl } \\
\text { group, and laxation effect at } 4 \text { hours } \\
\text { after methylnaltrexone use. } \\
\text { The anti-angiogenic and } \\
\text { immunomodulatory effects } \\
\text { of methylnaltrexone were } \\
\text { also confirmed. }\end{array}$ \\
\hline
\end{tabular}

02 randomized, double-blind, placebo-controlled clinical trial.

The 301-patient group had constipation within 48 hours and used morphine (mean dose $<150 \mathrm{mg} /$ day vs $\geq 150 \mathrm{mg} /$ day) and laxatives where 154 were randomized to $0.15 \mathrm{mg} / \mathrm{kg}$

2 groups with 30 and 302 palliative care patients with NALAMACHU a life expectancy et al. ${ }^{18} \quad$ of 1 to 6 months who developed opioid-induced constipation
Evaluate the efficacy and tolerability of methylnaltrexone in this population. subcutaneous methylnaltrexone

$(n=47)$ and $0.30 \mathrm{mg} / \mathrm{kg}(\mathrm{n}=55)$

or placebo $(n=52)$ for 28 days

followed by 3 months. The 302 group was randomized to 133 patients who had less than 03 bowel movements per week or no 48-hour bowel movement also on morphine and laxatives receiving subcutaneous methylnaltrexone $0.15 \mathrm{mg} / \mathrm{kg}$ $(n=62)$ and placebo $(n=71)$.
From the results, it was observed that $33 \%$ of the group that used $0.15 \mathrm{mg} / \mathrm{Kg}$ of drug evolved with a lot of constipation against $19 \%$ of those receiving $0.30 \mathrm{mg} / \mathrm{Kg}$ and placebo $36 \%$. Subcutaneous methylnaltrexone provides a fast, robust and consistent response in patients with advanced

disease with a favorable dose of $0.30 \mathrm{mg} / \mathrm{kg}$ in the population studied.

There were 163 patients with documented use of FPNS. The average duration of use was 325 days;

171 chronic bone cancer patients undergoing chronic

TAYLOR pain using at least et al..$^{9}$ $60 \mathrm{mg} /$ day of oral morphine or equivalent for an average of 325 days.
Investigate prolonged use of Fentanyl Pectin Nasal Spray (FPNS) for the treatment of progressive cancer pain in patients receiving regular opioid therapy.
Clinical trial with 171 chronic cancer pain patients on average $60 \mathrm{mg} /$ day oral morphine use and was conducted using FPNS at $100-800 \mu \mathrm{g}$ of physicianprescribed doses.

46 patients used FPNS for $\geq 360$ days;

the maximum duration was 44 months.

Seventy percent of patients did not change their dose of FPNS. The most common complaints were insomnia,

9.9\%; nausea, 9.4\%; vomiting, 9.4\%; and peripheral edema, $9.4 \%$. The overall incidence of FPNS-related complaints was $11.1 \%$, the most common being constipation (4.1\%), with no apparent dose relationship. Ten patients (5.8\%) had mild or moderate nasal complaints.

Compare the efficacy and safety of a continuous HUANG of morphine and intrathecal infusion et al. ${ }^{9}$
36 cancer patients received a of morphine and ropivacaine via an intrathecal catheter through a subcutaneous port. ropivacaine versus an intrathecal morphine alone for
Double-blind randomized trial.

Constipation was not observed as most patients treated with systemic opioids in this study were treated with

an intestinal stimulant, a stool softener or laxatives prior to intrathecal management. 


\begin{tabular}{|c|c|c|c|c|}
\hline Authors & Sample & $\begin{array}{l}\text { Objective of } \\
\text { the study }\end{array}$ & Methods & Results \\
\hline $\begin{array}{l}\text { KURITA } \\
\text { et al. }{ }^{20}\end{array}$ & $\begin{array}{l}1147 \text { cancer patients } \\
\text { on opioid treatment } \\
\text { to control cancer } \\
\text { pain, including: } \\
\text { morphine }(n=581) \text {, } \\
\text { oxycodone }(n=298) \text {, } \\
\text { and fentanyl } \\
(n=268) \text {, aged } 18 \\
\text { to } 80 \text { years old. }\end{array}$ & $\begin{array}{l}\text { Analyze whether } \\
\text { opioid symptoms } \\
\text { and adverse effects } \\
\text { of cancer patients } \\
\text { are associated } \\
\text { with reduced } \\
\text { renal function. }\end{array}$ & $\begin{array}{l}\text { Cross-sectional, randomized, } \\
\text { multicenter clinical trial of } \\
\text { 1,147 opioid-treated patients } \\
\text { (morphine/ oxycodone/ fentanyl) } \\
\text { from } 2005 \text { to } 2008 \text { for at least } \\
\text { O3 days where weight, height, } \\
\text { serum opioid and creatinine } \\
\text { concentrations were evaluated, } \\
\text { and symptoms progressed: } \\
\text { fatigue, nausea, vomiting, pain, } \\
\text { loss of appetite, constipation, } \\
\text { and cognitive dysfunction. }\end{array}$ & $\begin{array}{l}\text { Severe constipation and loss of } \\
\text { appetite associated with poor renal } \\
\text { function have been reported only } \\
\text { in patients with serum morphine } \\
\text { concentrations above ( } \geq 41.89 \mathrm{nmol} / \mathrm{L}) \text {. } \\
\text { The other two opioids from the } \\
\text { research appear to be safer in treating } \\
\text { cancer pain. Patients who had serum } \\
\text { oxycodone concentrations above } \\
\text { (> } 99.58 \text { nmol/L) were more likely to } \\
\text { report severe fatigue. Fentanyl-treated } \\
\text { patients had no complaints. }\end{array}$ \\
\hline $\begin{array}{l}\text { JANKU } \\
\text { et al. }{ }^{13}\end{array}$ & $\begin{array}{l}229 \text { patients with } \\
\text { advanced cancer } \\
\text { and } 134 \text { with other } \\
\text { opioid-treated } \\
\text { diseases and all } \\
\text { had opioid-induced } \\
\text { constipation. }\end{array}$ & $\begin{array}{c}\text { Evaluate the } \\
\text { effectiveness of } \\
\text { Methylnaltrexone- } \\
\text { MNTX in opioid- } \\
\text { induced palliative } \\
\text { care patients. }\end{array}$ & $\begin{array}{l}\text { Placebo-controlled randomized } \\
\text { controlled trial. Of the } 229 \\
\text { cancer patients, } 117 \text { ( } 51 \%) \\
\text { were treated with MNTX and } \\
112(49 \%) \text { were treated with } \\
\text { placebo during the double- } \\
\text { blind portion of the study. }\end{array}$ & $\begin{array}{l}\text { MNTX-treated patients were more } \\
\text { likely to have a response (laxation } \\
\text { within } 4 \text { hours after the first } \\
\text { administration) compared to } \\
\text { placebo-treated patients ( } 72 / 117, \\
62 \% \text { versus. } 5 / 112,4 \%, \mathrm{P}<0.001 \text { ). } \\
\text { It is concluded that methylnaltrexone, } \\
\text { which is used for the treatment of } \\
\text { opioid-induced constipation, could } \\
\text { positively influence patient survival. }\end{array}$ \\
\hline $\begin{array}{l}\text { HIGUCHI } \\
\text { et al. }{ }^{21}\end{array}$ & $\begin{array}{l}\text { A 14-year-old } \\
\text { female who } \\
\text { developed } \\
\text { an intrapelvic } \\
\text { tumor from the } \\
\text { lumbosacral spinal } \\
\text { cord detected since } \\
\text { she was } 4 \text { years old. }\end{array}$ & $\begin{array}{l}\text { Show the } \\
\text { effectiveness of } \\
\text { subarachnoid drug } \\
\text { use in a continuous } \\
\text { infusion pump } \\
\text { without sedation. }\end{array}$ & $\begin{array}{l}\text { Case study in which opioid } \\
\text { therapy and infusion of } \\
\text { subarachnoid drugs for pediatric } \\
\text { treatment were followed. } \\
\text { High doses of gabapentin, } \\
\text { tramadol, and pentazocine } \\
\text { were initially used, but could } \\
\text { not relieve pain progressing to } \\
\text { morphine administration } \\
50 \text { mg per day, and soon after, } \\
\text { subarachnoid bupivacaine pump } \\
\text { infusion was started. }\end{array}$ & $\begin{array}{l}\text { Although pain improved due to } \\
\text { sedation, the adolescent evolved } \\
\text { sedated and developed severe } \\
\text { constipation due to opioid-induced } \\
\text { paralytic ileus. sedation, improved } \\
\text { awareness of reading, eating and } \\
\text { watching TV, and improved bowel } \\
\text { function. In conclusion, continuous } \\
\text { infusion of subarachnoid drugs } \\
\text { provided effective analgesia, } \\
\text { decreased side effects of } \\
\text { systemic opioids. }\end{array}$ \\
\hline $\begin{array}{l}\text { FERNÁNDEZ } \\
\text { et al. }{ }^{22}\end{array}$ & $\begin{array}{c}99 \text { medical records } \\
\text { of children aged } 8 \\
\text { years and } 64.6 \% \\
\text { were male } \\
\text { on opioids } \\
0.5 \mathrm{mg} / \mathrm{kg} / \mathrm{h} \text {. }\end{array}$ & $\begin{array}{l}\text { Describe the } \\
\text { experience of using } \\
\text { opioids for pain } \\
\text { management in } \\
\text { pediatric advanced } \\
\text { cancer patients in } \\
\text { palliative care. }\end{array}$ & $\begin{array}{l}\text { Retrospective study of patients } \\
\text { admitted to the program } \\
\text { at Hospital Roberto del Río } \\
\text { between } 2002 \text { and } 2013\end{array}$ & $\begin{array}{l}\text { Two-thirds of the patients studied } \\
\text { required strong opioids, in which } \\
\text { adequate pain management was } \\
\text { obtained, with no serious complications } \\
\text { observed. The use of opioids in this } \\
\text { group of patients, following a protocol, } \\
\text { is considered effective and safe. } \\
\text { Form } 66 \text { patients taking strong opioids, } \\
89 \% \text { required less than } 0.5 \mathrm{mg} / \mathrm{kg} / \mathrm{h} \text {. } \\
\text { Constipation was the most commonly } \\
\text { observed side effect. }\end{array}$ \\
\hline $\begin{array}{l}\text { ROBERTO } \\
\text { et al. }{ }^{4}\end{array}$ & $\begin{array}{l}336 \text { cancer patients } \\
\text { with moderate to } \\
\text { severe pain treated } \\
\text { with Transdermal } \\
\text { Fentanyl - TDF and } \\
\text { oral Oxycodone- } \\
\text { Naloxone - OXN } \\
\text { (119 TDF and } 191 \\
\text { OXN) for } 28 \text { days. }\end{array}$ & $\begin{array}{l}\text { It aims to partially } \\
\text { bridge the } \\
\text { gap between } \\
\text { comparing the use } \\
\text { of TDF and OXN } \\
\text { in pain control and } \\
\text { the lower incidence } \\
\text { of opioid-induced } \\
\text { constipation. }\end{array}$ & $\begin{array}{l}\text { Prospective clinical trial with } \\
\text { cancer patients with moderate } \\
\text { to severe stage pain enrolled } \\
\text { consecutively in two 28-day } \\
\text { prospective trials, received TDF } \\
\text { or OXN-PR. To compare the } \\
\text { efficacy and safety of TDF and } \\
\text { OXN-PR, we used propensity } \\
\text { score analysis to adjust the } \\
\text { heterogeneity between the two } \\
\text { patient groups. }\end{array}$ & $\begin{array}{l}\text { The final daily dose of opioid expressed } \\
\text { as morphine equivalent was } 113.6 \mathrm{mg} \\
\text { for TDF and } 44.5 \mathrm{mg} \text { for OXN-PR. } \\
\text { Reports of opioid-induced constipation } \\
\text { were observed in both groups ( } 32.6 \% \\
\text { after TDF vs } 24.7 \% \text { after OXN-PR) } \\
\text { being lower in the group than OXN. } \\
\text { Gastrointestinal symptoms such as } \\
\text { nausea, vomiting and dry mouth } \\
\text { were significantly less frequent in the } \\
\text { OXN-PR group than in the TDF group. }\end{array}$ \\
\hline $\begin{array}{l}\text { NOSEK } \\
\text { et al. }{ }^{23}\end{array}$ & $\begin{array}{l}62 \text { cancer patients } \\
\text { treated at home } \\
\text { and ambulatory } \\
\text { care with a life } \\
\text { expectancy of } \\
\text { at least } 40 \text { days } \\
\text { without renal or } \\
\text { hepatic dysfunction } \\
\text { for } 28 \text { days. Only } 53 \\
\text { patients completed } \\
\text { the survey. }\end{array}$ & $\begin{array}{l}\text { Compare analgesic } \\
\text { effect and adverse } \\
\text { effects during } \\
\text { oral morphine, } \\
\text { oral oxycodone, } \\
\text { transdermal } \\
\text { fentanyl and } \\
\text { buprenorphine use } \\
\text { in cancer patients } \\
\text { with advanced pain. }\end{array}$ & $\begin{array}{l}\text { Randomized clinical trial in } \\
\text { which patients used morphine } \\
\text { 14, oxycodone } 16 \text {, fentanyl } 15 \\
\text { and buprenorphine } 17 \text { for } 28 \\
\text { days. All patients received } \\
10 \text { mL of lactulose as } \\
\text { constipation prophylaxis. }\end{array}$ & $\begin{array}{l}\text { Considering the effect of pain on } \\
\text { patients' overall activity, a slightly } \\
\text { better but insignificant effect of } \\
\text { morphine is observed compared to } \\
\text { other opioids. For bowel function, } \\
\text { no significant changes in constipation } \\
\text { symptoms were found during the } \\
\text { trial, however it is considered that all } \\
\text { patients received } 10 \mathrm{~mL} \text { lactulose } \\
\text { as prophylaxis. }\end{array}$ \\
\hline
\end{tabular}

Source: Articles found in research databases CAPES, VHL, SAGE Journals, Pubmed (2013-2017). 


\section{DISCUSSION}

Given the reviews of the studies, it is possible to observe that morphine is the opioid of choice to minimize cancer pain. The authors ${ }^{5}$ monitored cancer patients undergoing palliative care using oral morphine and investigated the side effects of morphine according to their serum concentrations, and concluded that the higher the serum drug dosages, the greater the complaints of side effects such as constipation.

Other researchers ${ }^{20}$ performed a clinical trial with 1,147 cancer patients receiving opioids (morphine, oxycodone, and fentanyl) and observed a reduction in glomerular filtration rate. The authors found that from these opioids the one presenting the most complaints of constipation and decreased appetite associated with low renal function were presented in patients with serum morphine concentrations above $(\geq 41.89 \mathrm{nmol} / \mathrm{L})$. The other two opioids from the research appear to be safer in treating cancer pain. Patients who had serum oxycodone concentrations above (> $99.58 \mathrm{nmol} / \mathrm{L}$ ) were more likely to report severe fatigue. Fentanyl-treated patients had no complaints.

In contrast, several studies emphasize the use of laxatives in combination with opioids to minimize or treat opioidinduced constipation. In palliative care, the authors ${ }^{17}$ highlight the use of laxative Methylnaltrexone. They studied a group of patients $(n=195)$ in palliative care in the treatment of opioid pain with emphasis on morphine, where they used methylnaltrexone, and had the effects of laxation as early as 4 hours after use. The authors of this study themselves suggest a randomized placebo study in a larger population. This is what the authors ${ }^{18}$ were able to accomplish with 02 groups of patients, one with $n=301$ and one with $n=302$, where they used different dosages of methylnaltrexone in patients using morphine (average dose $<150 \mathrm{mg} /$ day vs $>150$ $\mathrm{mg}$ /day), and concluded that subcutaneous methylnaltrexone provides a fast, robust and consistent response in patients with advanced disease with a favorable dose of $0.30 \mathrm{mg} / \mathrm{kg}$ in the population studied.

In a study ${ }^{23}$ in which prophylactic laxatives were used, it was shown that the experimental opioids showed similar profile and severity of adverse effects. Laxative prophylaxis prevented constipation. In this sense, another group of academics ${ }^{22}$ showed that the side effects recorded concerning the use of opioids of $83.4 \%$ in the patients and they had some type of side effect, the most frequent being constipation, highlighting the absence of serious effects such as respiratory depression and anaphylaxis. And concludes the study with the statement that it is necessary the prophylactic indication of laxatives, intestinal motility stimulants and antiemetics in pain therapy.

In another clinical trial ${ }^{13}$ with 229 cancer patients in palliative care who used opioids and developed constipation and evaluated the effectiveness of methylnaltrexone. And they observed the effect of laxation within 4 hours of use. The authors of this research also used Cochrane Collaboration database reviews to assess the risk of bias in methylnaltrexone randomized trials and concluded that the use of opioids associated with methylnaltrexone generates quality of life in palliative care.

The same laxation effect was observed in a case study ${ }^{15}$ with a male child with moderate to severe pain undergoing morphine therapy who used methylnaltrexone. And the authors suggest that opioid therapy should be done with a laxative. The option for methylnaltrexone is advocated for its antagonistic action to the effects of opioid binding on gut $\mu$-receptors, minimizing constipation and not decreasing opioid analgesia. They further suggest that intravenous morphine should be used at $150 \mathrm{mcg} / \mathrm{kg}$ to minimize constipation and prevent additional distress at this stage. Nonetheless, in the label of this drug, there is an observation that safety and efficacy have not yet been established in pediatric patients. And the use of this methylnaltrexone drug should be discouraged in patients with intestinal obstruction and should be used only with a prescription ${ }^{13,15,17}$. Therefore, regarding the use of medicines, it is up to the physician to observe and prescribe. It is noteworthy that this article is only an integrative review which lists the articles that suggest actions to minimize constipation and should not be used as random prescription criteria without the endorsement of the medicine professional specialized in the field.

Other suggestions to minimize constipation would be to change the route of drug use from being oral, as suggested by the clinical trial ${ }^{19}$ conducted with 171 patients using oral morphine $(60 \mathrm{mg} /$ day $)$ who developed constipation and suggested replacing opioids with a fentanyl (Lazanda ${ }^{\circ}$ ) pectin nasal spray. In this group that made the exchanges observed the most common complaints were insomnia, 9.9\%; nausea, 9.4\%; vomiting, 9.4\%; and peripheral edema, 9.4\%, and constipation in only $4.1 \%$, with no apparent dose relationship. Considering this group under study, only ten patients (5.8\%) had nasal complaints, most of them either mild or moderate. Concluding the research, the authors suggest that the use of this spray is in a controlled manner by the medical staff as it may lead to addiction, overdose and serious complications due to misuse.

Reports of constipation are also present in another study, where there was a lower prevalence of nausea and vomiting after opioid use and one possible explanation may be that the opioid antagonist naloxone acts at the gastric level through the same mechanism as in bowel dysfunction limitation, thereby reducing the development of nausea and vomiting.

In addition, another study ${ }^{21}$ corroborates the possibility of changing the opioid administration route, which showed that continuous subarachnoid drug delivery with an infusion pump provided effective analgesia, reduced the side effects of systemic opioids, and allowed a remarkable improvement in activities of daily living. This technique may be a viable option in palliative care.

In a study with 36 patients in palliative care who compared the efficacy of morphine and ropivacaine use via continuous intrathecal infusion, however, this study is not very successful regarding the results for controlling constipation, since patients who participated in the clinical trial, all used laxatives before the use of opioids, which generated bias 
of the results, therefore, masking them. So, it cannot be concluded the efficacy of opioid pathway exchanges to treat constipation through this study. The authors ${ }^{9}$ of this trial found that no constipation was observed in the group, which was already expected.

Thus, in a clinical trial ${ }^{24}$ of 11 patients undergoing palliative care using morphine to treat severe pain for 05 months, it was observed that the use of venous morphine minimized constipation versus oral administration and suggest studies with trials with a larger audience to improve the statement. Other authors ${ }^{16}$ observed psychological distress in patients ( $n=168$ ) who used opioids for more than 4 weeks in palliative care and found that depressive changes and anxiety disorder were related to constipation. Often the health team thinks of minimizing pain and forgets that side effects of medication can worsen the emotional of this population. Systematic review articles that presented results on opioid-induced constipation in palliative care are presented in Table 2.

Table 2 - Systematic review articles with meta-analysis and Cochrane addressing the theme of opioid-induced constipation in palliative care. Jequié, BA, Brazil, 2018

\begin{tabular}{|c|c|c|c|c|}
\hline Authors & Sample & $\begin{array}{l}\text { Objective of } \\
\text { the study }\end{array}$ & Methods & Results \\
\hline $\begin{array}{l}\text { SIEMENS } \\
\text { e BECKER }\end{array}$ & $\begin{array}{l}\text { O7 studies with } \\
1,860 \text { patients }\end{array}$ & $\begin{array}{l}\text { Evaluating the } \\
\text { effectiveness of } \\
\text { Methylnaltrexone } \\
\text { (MNTX) in patients } \\
\text { with opioid-induced } \\
\text { constipation. }\end{array}$ & $\begin{array}{l}\text { A systematic review with meta- } \\
\text { analysis was performed from } \\
\text { January } 2014 \text { to December } \\
21^{\text {st }}, 2015 \text {. Dichotomous meta- } \\
\text { analyzes with risk indices and } \\
\text { 95\% confidence intervals were } \\
\text { calculated using RevMan 5.3. }\end{array}$ & $\begin{array}{l}\text { The review results indicated that } \\
\text { patients on MNTX had higher stool } \\
\text { frequency and needed less time for } \\
\text { laxation compared with placebo. }\end{array}$ \\
\hline $\begin{array}{l}\text { CLARK e } \\
\text { CURROW }^{14}\end{array}$ & $\begin{array}{l}\text { There were found } \\
20 \text { articles. Only } 12 \\
\text { of the } 20 \text { articles } \\
\text { used their cited } \\
\text { definitions of } \\
\text { constipation as a } \\
\text { primary result of } \\
\text { the studies and } \\
\text { four randomized } \\
\text { and controlled } \\
\text { blind trials. }\end{array}$ & $\begin{array}{l}\text { Emphasizing issue } \\
\text { by systematically } \\
\text { examining eligibility } \\
\text { measures and } \\
\text { primary results in } \\
\text { constipation studies } \\
\text { in the population } \\
\text { of hospices and } \\
\text { palliative care. }\end{array}$ & $\begin{array}{l}\text { The survey was performed } \\
\text { using the validated care filter } \\
\text { developed by CareSearch } \\
\text { (www.caresearch.com.au), } \\
\text { an online care information } \\
\text { resource approved by Flinders } \\
\text { University (Australia) and funded } \\
\text { by the Australian federal } \\
\text { government. Published from } 1965 \\
\text { to } 2013 \text {. The research used articles } \\
\text { with randomized controlled trials, } \\
\text { cohort studies, or case studies. }\end{array}$ & $\begin{array}{l}\text { There was not a single set of } \\
\text { diagnostic criteria for constipation that } \\
\text { needed to be included in the study. } \\
\text { Since constipation is multifactorial, } \\
\text { especially in the population of } \\
\text { palliative care and sanatorium, several } \\
\text { factors can lead to constipation } \\
\text { such as progressive cachexia, } \\
\text { increased immobility, poor oral intake, } \\
\text { anticholinergic medications (including } \\
\text { opioids) and comorbidities that } \\
\text { include illness. }\end{array}$ \\
\hline $\begin{array}{l}\text { CANDY } \\
\text { et al. } .^{25}\end{array}$ & $\begin{array}{c}\text { O5 studies } \\
\text { involving } 370 \\
\text { people in palliative } \\
\text { care who used } \\
\text { laxatives }\end{array}$ & $\begin{array}{l}\text { Determining the } \\
\text { effectiveness of } \\
\text { laxatives for treating } \\
\text { constipation in } \\
\text { people receiving } \\
\text { palliative care }\end{array}$ & $\begin{array}{l}\text { Review of the Cochrane Central } \\
\text { Controlled Trials (The Cochrane } \\
\text { Library), MEDLINE, EMBASE, } \\
\text { CINAHL and Web of Science, } \\
\text { about the use of laxatives } \\
\text { in people with constipation in } \\
\text { palliative care until September } \\
\text { 2014. The most commonly } \\
\text { used laxatives were as follows: } \\
\text { lactulose, senna, co-danthramer } \\
\text { combined with poloxamer, } \\
\text { docusate and magnesium } \\
\text { hydroxide combined with liquid } \\
\text { paraffin. Misrakasneham has also } \\
\text { been rated, this is a traditional } \\
\text { Indian medicine. }\end{array}$ & $\begin{array}{l}\text { There was no evidence as to which } \\
\text { laxative provided the best treatment. } \\
\text { Still, the review was limited as the } \\
\text { evidence was only five small trials } \\
\text { and patient preference and cost } \\
\text { were assessed. Further testing is } \\
\text { needed to evaluate the effectiveness } \\
\text { of laxatives in palliative care } \\
\text { populations. Extrapolating findings } \\
\text { on the efficacy of laxatives evaluated } \\
\text { in other populations should be } \\
\text { done with caution. This is due to } \\
\text { the differences inherent in people } \\
\text { receiving palliative care. }\end{array}$ \\
\hline $\begin{array}{l}\text { WIFFEN, } \\
\text { DERRY e } \\
\text { MOORE }^{26}\end{array}$ & $\begin{array}{l}77 \text { studies with } \\
5619 \text { randomized } \\
\text { participants with } \\
\text { population aged } 50 \\
\text { to } 70 \text { years old. }\end{array}$ & $\begin{array}{l}\text { Determining the } \\
\text { impact of opioid } \\
\text { treatment on } \\
\text { patient awareness, } \\
\text { appetite, and thirst } \\
\text { in randomized } \\
\text { controlled trials of } \\
\text { morphine, fentanyl, } \\
\text { oxycodone or } \\
\text { codeine to treat } \\
\text { cancer pain. }\end{array}$ & $\begin{array}{l}\text { Systematic review with primary } \\
\text { data from randomized controlled } \\
\text { trials recommended by the UK } \\
\text { Ministry of Health included in } \\
\text { Cochrane reviews with current } \\
\text { data on the use of opioids to } \\
\text { treat cancer pain. }\end{array}$ & $\begin{array}{l}\text { For patients using } 04 \text { opioid doses } \\
\text { together, } 1 \text { in } 4 \text { people experienced } \\
\text { constipation and drowsiness, } 1 \text { in } 5 \\
\text { with nausea and dry mouth, and } 1 \text { in } \\
8 \text { with vomiting complained of } \\
\text { loss of appetite and dizziness. } \\
\text { The results showed complaints that } \\
\text { were affecting the quality of life due } \\
\text { to opioid use, with incidence rates of } \\
25 \% \text { for constipation, } 23 \% \text { drowsiness, } \\
21 \% \text { nausea, } 17 \% \text { dry mouth and } 13 \% \\
\text { vomiting, anorexia and dizziness. } \\
\text { Asthenia, diarrhea, insomnia, } \\
\text { hallucinations, and dehydration } \\
\text { occurred below } 5 \% \text {. }\end{array}$ \\
\hline
\end{tabular}

Source: Review articles published in the Cochrane database from 2013 to 2017 that address the theme proposed in this article. 
Given the systematic reviews found here, it was observed in a particular study ${ }^{26}$ that, opioids used to treat cancer pain, the incidence rates of adverse reactions were $25 \%$ for constipation, $23 \%$ for drowsiness, $21 \%$ for nausea, $17 \%$ for dry mouth, and 13\% for vomiting, anorexia, and dizziness. Asthenia, diarrhea, insomnia, mood swings, hallucinations, and dehydration occurred at incidence rates of $5 \%$ and below, similar results with other clinical trials ${ }^{20,22}$.

For other authors ${ }^{14}$, constipation remains poorly defined operationally by researchers and clinical trials that take care of this population. Because of this, their study seeks to use a research tool to validate the drug association with the consequent emergence of intestinal constipation, a study similar to a qualitative research ${ }^{24}$ already published.

In the research proposed by Siemens and Becker ${ }^{6}$, it was evidenced that the groups that used methylnaltrexone had a better improvement according to the "Assessment of the Patient's Life Quality" questionnaire. Patients in the methylnaltrexone and placebo groups improved by 33\%, $27 \%$, and $18 \%$, respectively. According to the results of the Global Clinical Change Impression, no dose-response relationship can be identified for the constipation disorder or the Assessment of the Patient's Life Quality related to Constipation, because of the differences between the groups in which they used methylnaltrexone were no statistical or clinically relevant. Some medical professionals in order to reduce opioid side effects prophylactically prescribe laxatives in the viable route of administration to the patient.

Considering the use of laxative in its most natural form, Candy et al. ${ }^{25}$ report that the randomized clinical trials in opioid palliative care patients included in this review showed no differences in the efficacy of three commonly used laxatives; senna, docusate and lactulose, in other words, there was no one laxative that stood out in the treatment of intestinal constipation. Nevertheless, these studies are subject to bias and low reaching. None of the studies have estimated the efficacy of polyethylene glycol in this population.

It was observed in the found studies that little is really addressed about the importance of diet with foods bearing a laxative effect, where the main measure in the face of constipation is the prescription of medicines, which needs further researching.

\section{FINAL CONSIDERATIONS}

It was possible to observe that the articles studied for the elaboration of the present work always brought some measures to treat opioid-induced constipation in some way, either by changing the route of administration of drug use, or by the prophylactic prescription of a laxative drug together with opioids, however, as it is a prescription drug, it is up to medical professionals to make such changes and apply possible suggestions.

It was also noted that little was mentioned about the importance of stimulating food consumption that favors laxative action in this public, such as the use of fiber-rich foods such as oats, papaya, plum, use of foods with probiotic action, the use of kefir and hydration stimulation for patients who still have a good glomerular filtration rate, as patients still believe in the power of the diet to control bowel constipation and because, naturally, it diminishes the psychological feeling of "using too many medications".

It is also an observation that patients in palliative care face physiological changes intrinsic to treatment such as lack of appetite, weight loss, nausea and vomiting, diarrhea, constipation, xerostomia (dry mouth), among other factors that interfere with nutritional status, which cannot close the diagnosis that constipation by itself was induced by opioids, which made it difficult to perform a meta-analysis in this study.

\section{REFERENCES}

1. Organização Mundial da Saúde. Alívio da dor do câncer. 2a ed. Genebra: Organização Mundial da Saúde. [Internet]. 1996 [Citado 2018 Out. 10]. Available from:http://apps.who.int/iris/ bitstream/10665/37896/1/9241544821.pdf

2. Caraceni A, Hanks G, Kaasa S, Bennett MI, Brunelli C, Cherny N, Haugen DF. Use of opioid analgesics in the treatment of cancer pain: evidence-based recommendations from the EAPC. The lancet oncology. 2012; 13(2):e58-e68. doi: https://doi.org/10.1016/S14702045(12)70040-2

3. Ripamonti CI, Santini D, Maranzano E, Berti M, Roila F. ESMO Guidelines Working Group. Management of cancer pain: ESMO clinical practice guidelines. Annals of oncology. 2012; 23(7):vii139vii154.doi: https://doi.org/10.1093/annonc/mds233

4. Roberto A, Greco MT, Legramandi L, Galli F, Galli M, Corli O. A comparison between the administration of oral prolonged-release oxycodone-naloxone and transdermal fentanyl in patients with moderate-to-severe cancer pain: a propensity score analysis. Journal of Pain Research. 2017: 10(1):2123. doi: 10.2147/JPR.S141928

5. Gretton SK, Ross JR, Rutter D, Sato H, Droney JM, Welsh KI, Riley J. Plasma morphine and metabolite concentrations are associated with clinical effects of morphine in cancer patients. Journal of pain and symptom management. 2013; 45(4):670-680. doi.org/10.1016/j. jpainsymman.2012.03.015

6. Siemens W \& Becker G. Methylnaltrexone for opioid-induced constipation: review and meta-analyses for objective plus subjective efficacy and safety outcomes. Therapeutics and clinical risk management. 2016; 12(1):401. doi: 10.2147/TCRM.S80749

7. Davis $M$ \& Gamier P. New options in constipation management. Current oncology reports. 2015; 17(12):55. doi:10.1007/s11912-0150481-x

8. World Health Organization. National cancer control programmes: policies and managerial guidelines. 2rd ed. Geneve: OMS. 2002. [Citado 2018 Out. 18]. Available from: http://www.who.int/cancer/ media/en/408.pdf

9. Huang Y, Li X, Zhu T, Lin J, Tao G. Efficacy and safety of ropivacaine addition to intrathecal morphine for pain management in intractable cancer. Mediators of inflammation, 2015; 2015(ID 439014):6.doi: http://dx.doi.org/10.1155/2015/439014

10. Cherny N, Ripamonti C, Pereira J, Davis C, Fallon M, McQuay H. Expert Working Group of the European Association of Palliative Care Network. Strategies to manage the adverse effects of oral morphine: an evidence-based report. Journal of Clinical Oncology. 2001; 19(9):2542-2554.doi: 10.1200/JCO.2001.19.9.2542

11. Rentz AM, Yu R, Müller-Lissner S, Leyendecker P. Validation of the Bowel Function Index to detect clinically meaningful changes in opioid-induced constipation. Journal of medical economics. 2009; 12(4):371-383. doi: 10.3111/13696990903430481

12. Bader S, Dürk T, Becker G. Methylnaltrexone for the treatment of opioid-induced constipation. Expert review of gastroenterology \& hepatology. 2013; 7(1):13-26. Doi: http://dx.doi.org/10.1586/egh.12.63

13. Jarmuż A, Banaszek M, Storr M, Fichna J. The Role of MOP and DOP Receptors in Treatment of Diarrheapredominant Irritable Bowel Syndrome. Mini reviews in medicinal chemistry. 2016; 16(18): 1462-1469. doi:10.2174/1389557516666160804165318 
14. Clark K, Currow DC. Constipation in palliative care: what do we use as definitions and outcome measures? Journal of pain and symptom management. 2013; 45(4):753-762. doi: https://doi.org/10.1016/j. jpainsymman.2012.03.016

15. Yeomanson D, Chohan O, Mayer A. Paediatric palliative care: intravenous methylnaltrexone relieves constipation. BMJ supportive \& palliative care. 2012; 3(1):103-105. doi: http://dx.doi.org/10.1136/ bmjspcare-2012-000291

16. Dhingra L, Shuk E, Grossman B, Strada A, Wald E, Portenoy A, Portenoy R. A qualitative study to explore psychological distress and illness burden associated with opioid-induced constipation in cancer patients with advanced disease. Palliative medicine. 2013; 27(5) 447-456.doi:10.1177/0269216312450358

17. Neefjes EC, Van der Vorst MJ, Boddaert MS, Zuurmond WW, Van der Vliet HJ, Beeker A, Verheul HM. Clinical evaluation of the efficacy of methylnaltrexone in resolving constipation induced by different opioid subtypes combined with laboratory analysis of immunomodulatory and antiangiogenic effects of methylnaltrexone. BMC palliative care. 2014; 13(1):42.doi: https://doi.org/10.1186/1472-684X-13-42

18. Nalamachu SR, Pergolizzi J, Taylor R, Slatkin NE, Barrett AC, Yu J, Forbes WP. Efficacy and Tolerability of Subcutaneous Methylnaltrexone in Patients with Advanced Illness and Opioid-Induced Constipation: A Responder Analysis of 2 Randomized, Placebo-Controlled Trials. Pain Practice. 2015; 15(6):564-571.doi: 10.1111/papr.12218

19. Taylor D, Radbruch L, Revnic J, Torres LM, Ellershaw JE, Perelman M. A report on the long-term use of fentanyl pectin nasal spray in patients with recurrent breakthrough pain. Journal of pain and symptom management. 2014; 47(6):1001-1007. doi:http://dx.doi.org/10.1016/j. jpainsymman.2013.07.012

20. Kurita GP, Lundström S, Sjøgren P, Ekholm O, Christrup L, Davies A Dale O. Renal function and symptoms/adverse effects in opioidtreated patients with cancer. Acta Anaesthesiologica Scandinavica. 2015; 59(8):1049-1059.doi: 10.1111/aas.12521

21. Higuchi T, Shimada K., Cho Y, Minami K., Takeuchi K., Sakamoto A. Effectiveness of subarachnoid drug infusion for pediatric tumorrelated pain. Pediatrics International. 2016; 58(8):760-763.doi: $10.1111 /$ ped. 12952

22. Fernández UB, Trevigno BA, Rodríguez ZN, Palma TC, Cid BL. Use of opioids in palliative care of children with advanced cancer. Revista chilena de pediatria. 2016; 87(2):96-101.doi: 10.1016/j. rchipe.2015.10.006

23. Nosek K, Leppert W, Nosek H, Wordliczek J, Onichimowski D. A comparison of oral controlled-release morphine and oxycodone with transdermal formulations of buprenorphine and fentanyl in the treatment of severe pain in cancer patients. Drug Design, Development and Therapy. 2017; 11(1):2409. doi: 10.2147/DDDT.S141007

24. Mazumdar A, Mishra S, Bhatnagar S, Gupta D. Intravenous morphine can avoid distressing constipation associated with oral morphine: a retrospective analysis of our experience in 11 patients in the palliative care in-patient unit. American Journal of Hospice and Palliative Medicine.2008; 25(4):282-284. doi: 10.1177/1049909108315913

25. Candy B, Jones L, Larkin PJ, Vickerstaff V, Tookman A, Stone P. Laxatives for the management of constipation in people receiving palliative care. The Cochrane Library. [Internet] 2015 [cited 2017 out. 22] Available from: 10.1002/14651858.CD003448.pub4

26. Wiffen PJ, Derry S, Moore RA. Impact of morphine, fentanyl oxycodone or codeine on patient consciousness, appetite and thirst when used to treat cancer pain. Cochrane Database Syst Rev, 5. 2014; (4). doi: 10.1002/14651858.CD011056

27. Ercole FF, Melo LSD, Alcoforado CLGC. Revisão integrativa versus revisão sistemática. Revista Mineira de Enfermagem. 2014; 18(1):9-12. doi: http://www.dx.doi.org/10.5935/1415-2762.20140001

Received in: 14/08/2018

Required revisions: 19/12/2018

Approved in: 15/02/2019

Publicado em: 24/08/2020

\section{Corresponding author}

Geslaney Reis da Silva

Address: Av. Contorno, 145, Primavera Vitória da Conquista/BA, Brazil

Zip code: $45.012-560$

Email address: gmreis21@gmail.com Telephone number: +55 (77) 99124-7770

Disclosure: The authors claim to have no conflict of interest. 